\title{
親の認知した臨時休業中の小学生の生活習慣の変化と ストレス反応との関連
}

\author{
高坂 康雅 和光大学

\begin{abstract}
Parental perception of the relationship between stress responses and the changes in lifestyle habits of elementary school students during a temporary leave of absence for COVID-19
\end{abstract} \\ Yasumasa Kosaka (Wako University)

\begin{abstract}
This study was conducted to investigate the relationship between stress responses and the lifestyle habit changes
\end{abstract} \\ of elementary school students during a temporary leave of absence from school during measures to prevent the \\ spread of COVID-19 infections. We surveyed 637 parents of elementary school students about their lifestyle habit \\ changes and stress responses during their temporary leave and finally analyzed 510 subjects. Variance analysis, \\ showed that there were significant differences in "irregular sleep," "disordered eating habits," and "increased use \\ of games and smartphones," but the effect size was small. When the correlation was calculated, "disordered eating \\ habits" was associated with all stress responses, and six lifestyle-related changes were associated with lethargy.
}

Key words: disturbance of lifestyle habits, stress response, adaptation to school, elementary school students, COVID-19.

The Japanese Journal of Psychology

2021, Vol. 92, No. 5, pp. 408-416

J-STAGE Advanced published date: August 30, 2021, https://doi.org/10.4992/jjpsy.92.20040

2020 年 4 月時点で, COVID-19（新型コロナウイル ス感染症）は世界的な感染拡大をみせている。日本政 府は 4 月 7 日付で 7 都府県に新型インフルエンザ等対 策特別措置法に基づく緊急事態宣言を発出し，4月 16 日には緊急事態宣言対象地域を全都道府県に拡大し た。この緊急事態宣言に先立って，2月 27 日に全国 の小学校, 中学校, 高等学校, 特別支援学校に対して, 3 月 2 日から春休みまで臨時休業を行うよう要請が出 された。文部科学省 (2020a) の調査によると，3月 16 日時点で臨時休業を実施した割合は公立小・中学 校で 99.0\%, 国立小・中学校では $100.0 \%$ であった。 この休業要請は 4 月以降も継続しており，4月 10 日 時点で新学期を開始した学校は，公立小学校で 33\%, 公立中学校で $34 \%$ となっている（文部科学省, 2020b)。このように, 多くの小・中学校では, 年間行 事には予定されていない形で, 長期の休業が行われて いる状況にある。

Correspondence concerning this article should be sent to: Yasumasa Kosaka, Wako University, Kanaicho, Machida, Tokyo 195-8585, Japan. (E-mail: ykosaka@wako.ac.jp)
学校における長期休業としては，夏休みや冬休みな どがあるが, これら長期休業と COVID-19感染拡大に よる臨時休業では, 大きく以下の 2 点で異なっている。 1 点目として，長期休業は年間行事予定のなかに明確 に位置づけられ，たとえば夏休みであれば，1学期の 終業式の後に始まり，2学期の始業式をもって終わる ことが明らかになっている。一方, 今回の臨時休業は 突然の休業要請により, 登校日が一日あった後に始ま り, 当初は臨時休業がいつ終わるのかも定かではな かった。2 点目として, 臨時休業要請を受け, 図書館 のような公的機関が休館や小・中学生の入館を認めな いなどの措置をとり, 習い事や学習塾も活動自肃をし たところが多くみられている。さらに, 密閉・密集・ 密接を避けることが求められることにより, 友人が集 まって遊ぶことも避けられ，公園でも閉鎖や遊具の使 用を禁止する措置がみられている。これらの措置によ り小学生は臨時休業期間中, 自宅以外, 日中に過ごす 場所がほとんどない状態であった。

このような状況におかれた子どもについて指摘され ているのが, ストレス反応の増加などメンタルヘルス の問題である。Jiao et al.（2020）では，中国において 
COVID-19 の感染が拡大した 1 月下旬から 2 月上旬に かけて行われた調查において，6歳から18 歳の子ど もに不注意や探索行動 (persistent inquiry), 不安や恐 怖などの感情反応が確認されたとしている。また,

Yeasmin et al. (2020) が封鎖下のバングラディッシュ において保護者を対象とした調查の結果，約 $50 \%$ の 子どもにうつや不安障害, 睡眠障害がみられたことを 明らかにしている。Kontoangelos, Economou, \& Papageorgiou（2020）は COVID-19 の感染による心理 的影響に関する論文のレビューを行い，子どもには急 性ストレス障害や適応障害，悲嘆，不安，恐怖などの 反応がみられることを指摘している。国内では，国立 成育医療研究センター (2020) が 2020 年 5 月に子と もと保護者を対象に行った調査において，学校の長期 休業や外出自肃の間に，不安や悲嘆を示す小学生が $30 \%$ 程度（「ときどきあった（週に 1,2 回）」以上を カウントした；以下同様），コロナに関連する場所や 活動を避ける小学生が $40 \%$ 程度, 怒りや痛㿉を示す 小学生が $50 \%$ 程度, 集中できなくなった小学生が $40 \%$ 程度いたことが明らかにされている。

このような子どものストレス反応とともに，長期休 業による子どもの生活習慣の変化も指摘されている (Bates et al., 2020)。たとえば, Medrano et al. (2020) によると，スペイン国内で外出禁止令が出された後で は，出される前よりも子どもの身体的活動は減少し， screen time（パソコンやスマホの視聴時間）やテレビ の視聴時間は増加し，睡眠時間も増加したことが示さ れている。また, Vanderloo et al. (2020) でも screen timeの増加が確認され，Lee（2020）では，睡眠時間 の乱れが指摘されている。国内でも，前述の国立成育 医療研究センター (2020) では, 長期休業のなかで, 外出時間の減少，身体を動かす遊びの減少，テレビや スマホ, ゲームを見ている時間の増加，睡眠時間のズ レが生じていることが報告されている。ベネッセ教育 総合研究所 (2020) が緊急事態宣言下の 2020 年 5 月 に母親を対象に行った調查でも，小学生の睡眠時間は 通常登校時よりも長くなり, ゲームや動画の利用・視 聴時間も長くなっており，特に低学年よりも高学年の 方が睡眠時間もゲームや動画の利用・視聴時間も長く なっていることが明らかにされている。この調查では, 低学年の母親の $52.1 \%$, 高学年の母親の $62.3 \%$ が「以 前より，生活習慣が乱れるようになった」と回答して おり，学習習慣についても $50 \%$ 程度の母親が乱れる ようになったと回答している。

生活習慣とストレス反応などメンタルヘルスとの間 には関連があることが指摘されている。たとえば，不 十分な睡眠は精神的健康や学習上のパフォーマンスに 重大な影響を及ぼす可能性が指摘されており（Paruthi et al., 2020 など)，服部・野々上・門田（2009）では, 心身の自覚症状の訴え数に対して, 小学生男子では睡
眠時間が，小学生女子では朝の目覚めの良し悪しが強 く関わっていることを明らかにしている。また加藤・ 大平・國土 (2014) でも不眠感が疲労感やいらいら感, 不安感に影響を及ぼしていることを示し, 小谷（2019） は適切な睡眠習慣をもつ小学生の方がストレス反応度 や抑うつ度が低いことを明らかにしている。Gregory \& Sadeh（2012）は睡眠とストレスの関連に関するレ ビューを行い，睡眠がストレスに影響を及ぼしている ことを示している研究が多いと指摘している。また, Macht（2008）はストレスの多い子どもは，ストレス への対処として不健康な食事を摂るようになると指摘 している。また山西・池田（2007）は，夕食の欠食や おやつなどの間食が心身の健康に関わっていることを 明らかにし，山田・木下・岡田（2018）は毎日朝食を 摂る小学生の方が疲労自覚症状は少なく, 心の健康状 態も良好であることを示している。他にも，身体的活 動が精神的健康に関わっていることが指摘されており (Janssen \& LeBlanc, 2010 など), 嘉数·井上·田場 (1999) は小学生の生活習慣とストレス反応との関連を検討 し, 外遊びの頻度や時間とストレス反応の「身体反応」 や「抑鬱・不安」との間には負の相関があることを示 している。上地・竹中・岡（2000）は生活習慣のなか でも身体活動水準は特にストレス反応との関連性が強 いことを示している。近年では, screen time が高スト レスと関連することも指摘されている（Biddle \& Asare, 2011)。

このような生活習慣とストレス反応との関連は平時 でもみられるが, COVID-19 の感染拡大による学校の 長期休業によって, 子どもの生活習慣が変化し, それ に伴ってストレス反応を示すようになっていることが 明らかになっている。Becker \& Gregory（2020）は COVID-19 感染拡大による外出禁止・自肃や学校の休 業が子どもの睡眠に影響を与えるとともに，不安や将 来の不確実感など多大なストレスを抱く可能性を指摘 している。Hu, Lin, Kaminga, \& Xu（2020）は感染拡大 以降，野菜や果物を食べなくなったり，朝食を食べな くなったりした子どもの方が主観的 well-being が低い ことを明らかにしている。

このように, COVID-19 感染拡大による学校の長期 休業は，子どもにストレスを与えるとともに，生活習 慣の変化を生じさせていると考えられる。しかし，学 校の長期休業期間中における子どもの生活習慣の変化 とストレス反応との関連について検討した研究は少な く(Hu et al., 2020), 日本国内でもみられていない。

そこで本研究では, COVID-19 の感染拡大防止のた めに行われた小学校の臨時休業期間における小学生の 生活習慣の変化とストレス反応との関連を検討するこ とを目的とする。また, ベネッセ教育総合研究所 (2020) の調査から, 低学年よりも高学年の方で生活習慣の変 化がみられることが推察されるため, 学年による生活 
Table 1

調査対象者の性別・在住都道府県 ·子どもの性別・学年

\begin{tabular}{|c|c|c|c|c|c|c|c|c|c|c|}
\hline \multirow{2}{*}{$\begin{array}{c}\text { 対象者の } \\
\text { 性別 }\end{array}$} & \multirow{2}{*}{$\begin{array}{c}\text { 子どもの } \\
\text { 性別 }\end{array}$} & \multirow{2}{*}{ 学年 } & \multicolumn{7}{|c|}{ 在住都道府県 } & \multirow{2}{*}{ 合計 } \\
\hline & & & 北海道·東北 & 関東 & 中部 & 関西 & 中国 & 四国 & 九州·沖縄 & \\
\hline \multirow{10}{*}{ 男性 } & \multirow{5}{*}{ 男子 } & 1 年生 & 2 & 6 & 5 & 5 & 1 & 0 & 4 & 23 \\
\hline & & 2 年生 & 1 & 10 & 3 & 8 & 1 & 1 & 2 & 26 \\
\hline & & 3 年生 & 2 & 8 & 7 & 6 & 1 & 0 & 1 & 25 \\
\hline & & 4 年生 & 3 & 7 & 3 & 6 & 2 & 1 & 1 & 23 \\
\hline & & 5 年生 & 1 & 7 & 5 & 3 & 2 & 0 & 2 & 20 \\
\hline & \multirow{5}{*}{ 女子 } & 1 年生 & 1 & 8 & 3 & 6 & 2 & 0 & 2 & 22 \\
\hline & & 2 年生 & 3 & 5 & 7 & 0 & 1 & 1 & 3 & 20 \\
\hline & & 3 年生 & 1 & 7 & 6 & 4 & 1 & 1 & 2 & 22 \\
\hline & & 4 年生 & 3 & 5 & 2 & 4 & 0 & 0 & 1 & 15 \\
\hline & & 5 年生 & 2 & 14 & 3 & 6 & 3 & 1 & 2 & 31 \\
\hline \multirow{11}{*}{ 女性 } & \multirow{5}{*}{ 男子 } & 1 年生 & 6 & 11 & 9 & 7 & 2 & 1 & 3 & 39 \\
\hline & & 2 年生 & 2 & 10 & 7 & 7 & 2 & 0 & 4 & 32 \\
\hline & & 3 年生 & 2 & 8 & 7 & 4 & 0 & 0 & 5 & 26 \\
\hline & & 4 年生 & 0 & 5 & 4 & 2 & 3 & 0 & 2 & 16 \\
\hline & & 5 年生 & 2 & 11 & 4 & 6 & 0 & 0 & 0 & 23 \\
\hline & \multirow{5}{*}{ 女子 } & 1 年生 & 5 & 8 & 9 & 7 & 3 & 1 & 2 & 35 \\
\hline & & 2 年生 & 6 & 7 & 5 & 2 & 2 & 2 & 2 & 26 \\
\hline & & 3 年生 & 2 & 12 & 4 & 10 & 2 & 1 & 7 & 38 \\
\hline & & 4 年生 & 1 & 9 & 7 & 5 & 3 & 0 & 1 & 26 \\
\hline & & 5 年生 & 0 & 6 & 7 & 4 & 0 & 3 & 2 & 22 \\
\hline & 合計 & & 45 & 164 & 107 & 102 & 31 & 13 & 48 & 510 \\
\hline
\end{tabular}

注）在住都道府県の区分は以下の通りである。北海道・東北：北海道, 青森県, 秋田県, 岩手県, 宮城県, 山形県, 福島県。関東：茨 城県, 栃木県, 群馬県, 埼玉県, 千葉県, 東京都, 神奈川県。中部 : 新潟県, 富山県, 石川県, 福井県, 長野県, 山梨県, 岐阜県, 静 岡県, 愛知県。関西：奈良県, 滋賀県, 三重県, 大阪府, 京都府, 和歌山県, 兵庫県。中国 : 島根県, 鳥取県, 岡山県, 広島県, 山口 県。四国 : 香川県, 高知県, 徳島県, 愛媛県。九州・沖縄 : 福岡県, 佐賀県, 長崎県, 熊本県, 大分県, 宮崎県, 鹿児島県, 沖縄県。

習慣の変化の差異についても，探索的に検討すること とする。

生活習慣について, 中岡・野田・山田・並木・五関 一曽根（2019）は，食習慣，睡眠時間，運動習慣につ いて尋ねている。また，長谷川・柳川・關・赤松 (2018) では, 食習慣, 運動習慣, 睡眠習慣, テレビ等の習慣 を尋ね, 日本学校保健会（2018）ではライフスタイル として, 運動, 食事, 睡眠 - 休養, 起床, 排便, 身体 活動, 食生活, 家庭での手伝い, 家庭学習, 塾, 稽古 事, コンピューターゲーム・テレビなどのメディア， SNS・インターネット, 部活動, 日常での身体活動, 体型とダイエット行動を尋ねている。前述の Bates et al. (2020)では COVID-19 による学校の休業によって, 身体的活動の減少, 睡眠習慣の乱れ, screen time など 座ったままの状態の持続が生じると指摘している。そ こで, 本研究では, これら先行研究において共通で尋 ねられていたり，長期休業によって増減したりすると 考えられるものとして，(a) 睡眠，（b）食事，(c）学 習，（d）外出，（e）テレビ・インターネット視聴，（f） 運動，（g）ゲーム・スマートフォン利用の 7 領域を設 定することとする。

\section{方 法}

\section{分析対象者}

本研究では, 小学校が臨時休業中であり, 小学生本 人に直接調査を実施することが困難であるため, 小学 生の親を対象として調査を実施した。既婚者であり, 公立小学校の普通学級に通う小学 $1-5$ 年生の子ども がおり，3月 2 日の全国休業措置から終業式にあたる 日までに「数日登校日はあったが原則休業であった」 か「一日も登校日のない完全な休業であった」とした 510 名（男性 227 名, 女性 283 名; 平均年齢 42.9 歳, 標準偏差 7.8 歳）を分析対象者とした。

対象者の子どもは, 1 年生が 119 名（男児 62 名, 女児 57 名), 2 年生が 104 名 (男児 58 名, 女児 46 名), 
3 年生が 111 名（男児 51 名, 女児 60 名), 4 年生が 80 名（男児 39 名，女児 41 名），5年生が 96 名（男児 43 名，女児 53 名）であった。 2020 年 3 月 2 日から終 業式にあたる日までの子どもの登校日数は「登校なし」 が 168 名 (32.9\%)，「1-3 日」が 318 名 (62.4\%)，「4 一8 日」が 19 名 $(3.7 \%)$ ，「9-12 日」が5名 (1.0\%) であった。対象者の性別, 子どもの性別と学年, 在住 都道府県の組み合わせについては, Table 1にまとめた。

なお，小学 6 年生については，卒業式が行われない あるいは簡略化して行われている，中学校という新し い学校に移行するなど，他の学年とは異なる状況にお かれていると考えられるため, 調查対象とはしなかっ た。

\section{調查時期及び調查方法}

2020 年 3 月 26 日及び 27 日に，アイブリッジ株式 会社のリサーチ事業“Freeasy”が保有しているモニ ター5,000 名を対象に web 上でのスクリーニング調査 を実施した。スクリーニング調査から，（a）既婚者で あり，2019年度において公立小学校の普通学級に通 う小学 1 - 5 年生の子どもがいる（小学生の子どもが 複数いる場合は, 年少の子どもについて回答を求め た)，(b) その子どもが通っている小学校が 3 月 2 日 の全国の小学校などにおいて休業措置が行われてから 終業式にあたる日までに，「数日登校日はあったが原 則休業であった」か「一日も登校日のない完全な休業 であった」，という2つの条件を満たした 637 名（男 性 287 名，女性 350 名）を抽出した。次に，2020 年 3 月 30 日及び 31 日に, 抽出した 637 名を対象に web 上での本調查を実施した。（a）すべて同じ選択肢に回 答している，（b）ダミー項目（「この項目は「あまり あてはまらない」と答えてください」）に扔いて指示 された回答とは異なる回答をしている，という 2 点を 不適切な回答として扱い，不適切な回答をした者を除 いた者を分析対象者とした。

\section{調查内容}

子どもの性別，年齢，2020 年 3 月 2 日から終業式 にあたる日までの子どもの登校日数のほかに，以下の 質問への回答を求めた。

臨時休業期間中の生活習慣の変化 事前に設定した （a）睡眠，（b）食事，（c）学習，（d）外出，（e）テレ ビ・インターネット視聴，(f) 運動，（g）ゲーム・ス マートフォン利用の 7 領域について, 各 3 項目を作成 して使用した (付録参照)。「以下の項目は，お子さん の休業期間中の様子・変化にどの程度あてはまります か」という教示のもと，1「まったくあてはまらない」 から $5\lceil$ 「てもあてはまる」の 5 件法で回答を求めた。

ストレス反応 臨時休業期間中の子どものストレス を測定するため, 岡安・由地・高山（1998）の児童用
メンタルヘルス・チェックリスト（簡易版）を使用し た。この尺度は子どものストレス状態を把握するため の尺度であり，「身体的症状」(項目例「体がだるい」), 「抑うつ・不安」(項目例「なんとなく，心配だ」)，「不 機嫌·怒り」(項目例「いらいらする」)，「無力感」(項 目例「体から力がわかない」）の 4 下位尺度各 3 項目 で構成されている。岡安他（1998）では，ストレス反 応尺度, 学校ストレッサー尺度, ソーシャルサポート 尺度との関連を検討し，いずれも強い相関が示されて いる。信頼性については，岡安他（1998）では言及さ れていない。

本研究では，親が子どもについて回答できるよう， 表現の修正を行って使用した(たとえば,「体がだるい」 は「体がだるそうだった」とし、「なんとなく,心配だ」 は「なんとなく,心配そうだった」とした)。教示文， 選択肢は「臨時休業期間中の生活習慣の変化」と同様 であった。

\section{倫理的配慮}

著者が“Freeasy”より得られる調查対象者個人に 関する情報は，年齢，在住都道府県，性別，婚姻状況 (既婚 / 未婚), 職業・業種, 世帯年収, 居住形態（持 ち家，梖貸，社宅など)，子どもの有無であり，氏名 など個人を特定し得る情報は取得できない。調查対象 者は調查対象者個人を特定し得る情報が提供されない ことや上記の個人に関する情報が提供されることに同 意し, “Freeasy”のモニターとして登録しており，本 研究でもこの同意が適用されている。調査実施の際に はスクリーニング調査及び本調査のいずれにおいて も，「小学校長期休校が子どもに及ぼす影響に関する 調査」と題し, 学術研究のためのアンケートであり, 得られたデータはスクリーニングあるいは学術研究の ために用いられること，個人が特定されない形で統計 的に処理されたデータとして利用されることをアン ケート導入前のトップページで示した。得られたデー 夕は著者以外が無断で閲覧, 利用することのないよう 管理された。調查に回答するかどうかは対象者自身の 自由意思であり，回答をしなかったり，途中でやめた りしたことによる不利益は一切生じないことも事前に 同意されており，本研究でも適用された。回答した者 にはアイブリッジ株式会社より規定に基づいたポイン トが付与された。なお，著者の所属機関には倫理審査 委員会はないため, 倫理審查等は受けていない。調査 内容については，人権侵害やプライバシーの侵害など 倫理的な問題が生じないよう十分吟味，検討したうえ で，調查を実施した。

\section{結 果}

本研究の分析は, IBM SPSS Statistics 22 を使用した。 
Table 2

生活習慣の変化に関する得点の $\alpha$ 係数と平均 ・標準偏差

\begin{tabular}{lccc}
\hline \multicolumn{1}{c}{ 領域 } & $\alpha$ 係数 & 平均 & 標準偏差 \\
\hline 不規則な睡眠 & .81 & 3.33 & 1.05 \\
食習慣の乱れ & .76 & 2.81 & 0.94 \\
学習時間の減少 & .81 & 3.42 & 0.96 \\
外出の減少 & .71 & 4.31 & 0.80 \\
テレビ・ネット視聴の増加 & .85 & 3.81 & 0.95 \\
運動の減少 & .67 & 3.98 & 0.77 \\
ゲーム・スマホ利用の増加 & .74 & 3.71 & 0.96 \\
\hline
\end{tabular}

注)「外出の減少」は 2 項目, 他の 6 領域は 3 項目での值である。

\section{臨時休業期間中の生活習慣の変化に関する項目の $\alpha$ 係 数と得点化}

臨時休業期間中の生活習慣の変化については，事前 に設定した 7 領域各 3 項目について $\alpha$ 係数を算出した ところ,「外出の減少」以外の 6 領域については, 3 項目での $\alpha$ 係数が . 67 - 85 と許容できる程度の值を示 した。一方,「外出の減少」は 3 項目での $\alpha$ 係数が. 57 と低かったため， $\alpha$ 係数を低めている 1 項目（「買い 物や遊び, 散歩などで外に出るようにしていた」(逆 転項目））を除いた 2 項目で算出し直すと，.71 となっ た。そこで,「外出の減少」は 2 項目の平均を, 他の 6 領域については 3 項目の平均を算出し, 各得点とし た。各領域の $\alpha$ 係数と平均, 標準偏差を Table 2 にま とめた。

\section{生活習慣の変化とストレス反応に関する学年間比較}

まず，臨時休業期間中のストレス反応 4 下位尺度に ついて，元の尺度をもとに $\alpha$ 係数を算出した。その結 果, 「身体的症状」が.89, 「抑うつ・不安」が.88, 「不 機嫌・怒り」が.92,「無気力」が.87と，いずれも十 分な内的一貫性が確認された。そこで, 各下位尺度の 項目の平均を算出し, 各下位尺度得点とした。

生活習慣の変化 7 得点とストレス反応 4 得点の学年 差を検討するため, 学年を要因とした一要因分散分析 を行った（Table 3）。その結果, 生活習慣の変化の「不 規則な睡眠」得点 $\left(F(4,505)=3.08, p<.05, \eta^{2}=.02\right)$,

$\lceil$ 食習慣の乱れ」得点 $(F(4,505)=2.57, p<.05$, $\left.\eta^{2}=.02\right)$,「ゲーム・スマホ利用の増加」( $F(4$, $\left.505)=3.17, p<.05, \eta^{2}=.02\right)$, ストレス反応の「抑うつ・ 不安」得点 $\left(F(4,505)=2.42, p<.05, \eta^{2}=.02\right)$ におい て要因の効果が有意であった。そこで, 多重比較 （Tukey 法）を行ったところ，「不規則な睡眠」得点で は 5 年生が 1 年生よりも高く,「食習慣の乱れ」得点 では 5 年生が 2 年生よりも高く,「ゲーム・スマホ利 用の増加」得点では 5 年生と 3 年生が 1 年生よりも高 かったが, いずれも効果量 $\left(\eta^{2}\right)$ は.02 と小さいもの
であった。また「抑うつ・不安」得点では多重比較の 結果, 有意な学年差はみられなかった。

\section{生活習慣の変化とストレス反応との関連}

生活習慣の変化とストレス反応との関連を検討する ために, 生活習慣の変化 7 得点とストレス反応 4 得点 の相関係数を算出した (Table 4)。

その結果,「不規則な睡眠」得点は「身体的症状」 得点,「無気力」得点と有意な正の相関を示し，「食習 慣の乱れ」得点や「テレビ・ネット視聴の増加」得点 はストレス反応 4 得点すべてと有意な正の相関を示し た。「学習時間の減少」得点は「抑うつ・不安」得点 を除く 3 得点と有意な正の相関を示し，「ゲーム・ス マホ利用の増加」得点は「無気力」得点と有意な正の 相関を示した。「外出の減少」得点と「運動の減少」 得点は「身体的症状」得点と有意な負の相関を示し, 「無気力」得点と有意な正の得点を示した。

\section{考察}

\section{臨時休業期間における小学生の生活習慣の変化とスト レス反応}

本研究の目的は, COVID-19 の感染拡大防止のため に行われた小学校の臨時休業期間における小学生の生 活習慣の変化とストレス反応との関連について, 親の 認知をもとに検討することであった。

まず，学年による生活習慣の変化やストレス反応の 比較を行ったところ, 生活習慣の「不規則な睡眠」,「食 習慣の乱れ」,「ゲーム・スマホ利用の増加」において, 有意な差がみられ, 特に 5 年生で高い得点が示された。 国立成育医療研究センター（2020）では，子どもの寝 る時間・起きる時間について「変わらない」と回答し た保護者は, 低学年が $40 \%$ であったのに対し, 高学 年は $30 \%$ であった。一方で,「テレビやスマホ, ゲー ムなどをみている時間」については, 低学年の $85 \%$, 高学年の $86 \%$ が「今の方が長い」と回答しており, 低学年・高学年でそれほど違いはみられていない。ま た, ベネッセ教育総合研究所（2020）では，2020年 1 月と比べて緊急事態宣言・学校長期休業期間にあたる 2020 年 5 月の方が, 低学年で 10 分, 高学年で 22 分 睡眠時間が長くなっており，「以前より，生活習慣が 乱れるようになった」と回答している保護者は, 低学 年で $52.1 \%$ ，高学年で $62.3 \%$ であったことを明らかに している。一方, 通常登校時に比べて休校時の方が勉 強や食事, 睡眠に関する声かけが増え, テレビやゲー ムの使い方について子どもと話し合う割合も増えたこ とが示されている。この調査では学年別の結果は示さ れていないが, 子どもが低学年であるほど, 小学校や 学童保育が臨時休業するなか, 保護者も仕事を休み, 生活をともにしていると考えられる。低学年であるほ 
Table 3

生活習慣の変化 7 得点及びストレス反応 4 得点の分散分析結果

\begin{tabular}{|c|c|c|c|c|c|c|c|c|}
\hline & & $\begin{array}{l}1 \text { 年生 } \\
\text { (119 名) }\end{array}$ & $\begin{array}{l}2 \text { 年生 } \\
\text { (104 名) }\end{array}$ & $\begin{array}{l}3 \text { 年生 } \\
\text { (111 名) }\end{array}$ & $\begin{array}{l}4 \text { 年生 } \\
(80 \text { 名) }\end{array}$ & $\begin{array}{l}5 \text { 年生 } \\
\text { (96 名) }\end{array}$ & $F$ 值 $(d f=4,505)$ & $\begin{array}{c}\text { 効果量 } \\
\left(\eta^{2}\right)\end{array}$ \\
\hline \multirow[t]{7}{*}{$\begin{array}{l}\text { 生活習慣 } \\
\text { の変化 }\end{array}$} & 不規則な睡眠 & $\begin{array}{l}3.15 \\
(0.94)\end{array}$ & $\begin{array}{c}3.19 \\
(1.11)\end{array}$ & $\begin{array}{c}3.32 \\
(1.11)\end{array}$ & $\begin{array}{c}3.51 \\
(1.05)\end{array}$ & $\begin{array}{c}3.56 \\
(1.01)\end{array}$ & $\begin{array}{c}3.08^{*} \\
1 \text { 年生 }<5 \text { 年生 }\end{array}$ & .02 \\
\hline & 食習慣の乱れ & $\begin{array}{c}2.85 \\
(0.93)\end{array}$ & $\begin{array}{c}2.55 \\
(0.98)\end{array}$ & $\begin{array}{c}2.89 \\
(1.00)\end{array}$ & $\begin{array}{c}2.82 \\
(0.85)\end{array}$ & $\begin{array}{c}2.92 \\
(0.95)\end{array}$ & $\begin{array}{c}2.57^{*} \\
2 \text { 年生 }<5 \text { 年生 }\end{array}$ & .02 \\
\hline & 学習時間の減少 & $\begin{array}{l}3.32 \\
(0.90)\end{array}$ & $\begin{array}{l}3.29 \\
(1.01)\end{array}$ & $\begin{array}{l}3.45 \\
(0.96)\end{array}$ & $\begin{array}{l}3.42 \\
(0.91)\end{array}$ & $\begin{array}{l}3.63 \\
(0.98)\end{array}$ & 1.94 & .02 \\
\hline & 外出の減少 & $\begin{array}{c}4.26 \\
(0.83)\end{array}$ & $\begin{array}{c}4.29 \\
(0.87)\end{array}$ & $\begin{array}{c}4.34 \\
(0.79)\end{array}$ & $\begin{array}{c}4.32 \\
(0.78)\end{array}$ & $\begin{array}{c}4.37 \\
(0.71)\end{array}$ & 0.30 & .00 \\
\hline & $\begin{array}{l}\text { テレビ・ネット } \\
\text { 視聴の増加 }\end{array}$ & $\begin{array}{c}3.74 \\
(0.93)\end{array}$ & $\begin{array}{c}3.70 \\
(0.92)\end{array}$ & $\begin{array}{c}3.91 \\
(0.95)\end{array}$ & $\begin{array}{l}3.70 \\
(1.02)\end{array}$ & $\begin{array}{l}3.99 \\
(0.92)\end{array}$ & $1.97^{\dagger}$ & .02 \\
\hline & 運動の減少 & $\begin{array}{c}3.90 \\
(0.77)\end{array}$ & $\begin{array}{c}3.91 \\
(0.73)\end{array}$ & $\begin{array}{c}4.03 \\
(0.77)\end{array}$ & $\begin{array}{l}3.99 \\
(0.79)\end{array}$ & $\begin{array}{c}4.06 \\
(0.79)\end{array}$ & 0.86 & .01 \\
\hline & $\begin{array}{l}\text { ゲーム・スマホ } \\
\text { 利用の増加 }\end{array}$ & $\begin{array}{c}3.46 \\
(0.94)\end{array}$ & $\begin{array}{c}3.70 \\
(0.87)\end{array}$ & $\begin{array}{c}3.82 \\
(1.01)\end{array}$ & $\begin{array}{c}3.75 \\
(0.94)\end{array}$ & $\begin{array}{c}3.89 \\
(0.99)\end{array}$ & $\begin{array}{c}3.17^{*} \\
1 \text { 年生 }<3 \text { 年生 } \cdot 5 \text { 年生 }\end{array}$ & .02 \\
\hline \multirow[t]{4}{*}{$\begin{array}{l}\text { ストレス } \\
\text { 反応 }\end{array}$} & 身体的反応 & $\begin{array}{l}1.89 \\
(0.93)\end{array}$ & $\begin{array}{l}1.93 \\
(0.91)\end{array}$ & $\begin{array}{c}2.06 \\
(0.93)\end{array}$ & $\begin{array}{l}2.04 \\
(0.78)\end{array}$ & $\begin{array}{c}1.88 \\
(0.73)\end{array}$ & 0.95 & .01 \\
\hline & 抑うつ・不安 & $\begin{array}{c}2.49 \\
(1.03)\end{array}$ & $\begin{array}{c}2.35 \\
(0.98)\end{array}$ & $\begin{array}{c}2.47 \\
(0.94)\end{array}$ & $\begin{array}{c}2.54 \\
(0.82)\end{array}$ & $\begin{array}{c}2.17 \\
(0.81)\end{array}$ & $\begin{array}{c}2.42 * \\
\text { (有意差なし) }\end{array}$ & .02 \\
\hline & 不機嫌・怒り & $\begin{array}{c}2.31 \\
(1.08)\end{array}$ & $\begin{array}{c}2.19 \\
(0.97)\end{array}$ & $\begin{array}{c}2.40 \\
(1.06)\end{array}$ & $\begin{array}{l}2.26 \\
(0.93)\end{array}$ & $\begin{array}{c}2.07 \\
(0.84)\end{array}$ & 1.62 & .01 \\
\hline & 無気力 & $\begin{array}{c}2.53 \\
(0.93)\end{array}$ & $\begin{array}{c}2.53 \\
(0.98)\end{array}$ & $\begin{array}{c}2.79 \\
(1.03)\end{array}$ & $\begin{array}{c}2.73 \\
(0.84)\end{array}$ & $\begin{array}{c}2.73 \\
(0.88)\end{array}$ & 1.82 & .01 \\
\hline
\end{tabular}

注）セルの上段の数值は平均, 下段の（ ）内の数值は標準偏差である。

${ }^{*} p<.05,{ }^{\dagger} p<.10$

Table 4

生活習慣の変化 7 得点とストレス反応 4 得点との相関

\begin{tabular}{lcccc}
\hline & 身体的症状 & 抑うつ・不安 & 不機嫌・怒り & 無気力 \\
\hline 不規則な睡眠 & $.11^{*}$ & .06 & $.09^{\dagger}$ & $.33^{* * *}$ \\
食習慣の乱れ & $.42^{* * *}$ & $.29 * * *$ & $.33^{* * *}$ & $.47 * * *$ \\
学習時間の減少 & $.09^{*}$ & .06 & $.15^{* *}$ & $.51^{* * *}$ \\
外出の減少 & $-.14 * *$ & .01 & -.05 & $.09^{*}$ \\
テレビ・ネット視聴の増加 & $.10^{*}$ & $.13^{* *}$ & $.15^{* *}$ & $.38^{* * *}$ \\
運動の減少 & $-.16^{* * *}$ & -.02 & .00 & $.22^{* * *}$ \\
ゲーム・スマホ利用の増加 & .02 & .02 & .02 & $.23 * * *$ \\
\hline$* * * p<.001, * * p<.01, * p<.05,{ }^{\dagger} p<.10$ & & &
\end{tabular}

ど, 一緒に過ごす時間のなかで, 子どもの生活などに ついて親が指示したり統制したりすることがしやすい と考えられるため, 高学年（5 年生）に比べ低学年の 方が生活習慣の変化に関する得点が低かったと推察さ れる。ただし, 効果量はいずれも 0.2 と小さかった。 また，ストレス反応では有意な差がみられなかったこ とを考慮すると, 今回の臨時長期休業による生活習慣 やメンタルヘルスへの影響は, 学年によって多少の差 異はあるものの，どの学年の子どもにも一定程度の生
活習慣の変化やストレス反応を生じさせたと保護者が 認識していたと考えられる。このことは，親からみる と, 小学校が臨時長期休業になったことや，長期休業 期間の公的施設をはじめとする子どもを取り巻く環境 は，学年にかかわらず，子どものメンタルヘルスに同 程度に影響を及ぼした受け止めていることを示唆し ていると考えられる。

次に, 生活習慣の変化とストレス反応との関連を検 討したところ，「食習慣の乱れ」が4つのストレス反 
応すべてと有意な弱いまたは中程度の正の相関を示し た。山田他（2018）は望ましい食習慣・食意識の子ど もほど疲労自覚症状が少ないことを明らかにしてい る。また辻本・奥田・小山・由田（2014）は食習慣（特 に朝食の食習慣）がだるさやめまいのような身体症状 だけでなく，学習意欲など様々な側面にポジティブな 影響を与えるとともに，望ましい就寝・起床時間とも 関わっており, 生活全般の状況を反映する指標となり 得るとしている。これらの知見から，食習慣の乱れが 心身のストレス反応全般と関わっていることは妥当な 結果であると考えられる。

また,「食生活の乱れ」以外にも,「不規則な睡眠」, 「学習時間の減少」,「テレビ・ネット視聴の増加」, 「運 動の減少」,「ゲーム・スマホ利用の増加」が「無気力」 と弱いまたは中程度の正の相関を示した。栗山・田中・ 園田・柴田（2001）は小学生において, 就寝時間が遅 い, 勉強時間が短い, テレビ視聴時間やゲーム時間が 長いほど無気力感が高いことを明らかにしている。本 研究では親を対象に調査を実施したが, 栗山他（2001） と同じく, 多くの生活習慣の変化が無気力と関連して いた。小学生は小学校を中心とした生活を送っている と考えられる。小学校に間に合うように起床し, 朝食 を食べ, 登校し，そこで学習をしたり，友人と交流し たりして，下校し，翌日の学校生活に影響が出ないよ うに就寝する。そのなかで, 家庭での宿題やテレビ ・ ネットの視聴, ゲーム・スマホの利用が行われたり, 習い事や塾に通っていたりしているといえる。そのよ うな生活の中心である小学校が長期に休業すること は，食生活に限らず，全般的な生活習慣・リズムを変 化させるとともに，子どもの登校・学習意欲の低下や 友人との交流を含めた活発な活動の低減を引き起こ し，親からみてそのような子どもが無気力な状態にあ ると認知されたと考えられる。

全般的に, 生活習慣の変化とストレス反応との間に おいて有意な相関がみられているものは正の相関であ るが,「外出の減少」と「運動の減少」は身体的症状 と有意な負の相関を示した。外出や運動は本来ストレ ス反応を低減させる効果が指摘されている（上地・田 中・長岡, 2008 など)。しかし, COVID-19の感染対 策として, 密閉・密集・密接を避けることや, 不要不 急の外出を避けることなどが, テレビなどで報道され， また臨時休業にあたり学校でも周知されたと推測され る。このようななかで, 運動や外出を控えることは適 切な行動であり，そのような適切な行動をとることが 身体的症状の低さと関連づけられて親に認知されたと 考えられる。また, 運動や外出を減らすことで, COVID-19に感染するリスクを低減させることがで き，そのリスクの低減が身体的症状の低さにつながつ た可能性も考えられる。ただし, これらの関連は-.14, -.16 とかなり弱いものであり, 結果の解釈や一般化に
は留意が必要である。また, 本研究は, 臨時休業が始 まった 3 月 2 日から約 1 力月後に行った調査である。 1 力月という比較的短い期間であれば，運動や外出を 控えることは身体的症状と負の関連を示すかもしれな いが, 多くの学校で臨時休業は 6 月頃まで継続した。 3 カ月間という長い期間運動や外出を控えることは, 短期間では生じなかった，あるいは抑制されていたス トレス反応を生じさせる可能性もあると考えられる。 このように, 生活習慣の変化とストレス反応との関連 については，短期的な関連と長期的な関連を区別する 必要があると考えられる。その点から, 本研究でみら れた運動・外出の減少と身体的症状との間の負の関連 は, 短期的な関連であるとして, 理解することが求め られる。

\section{本研究の課題と今後の展望}

本研究では, 長期休業期間中の小学生の生活習慣の 変化とストレス反応との関連を親の認知をもとに検討 した。その結果, 長期休業によって生活習慣が変化す るとともに無気力が生じ, 特に食習慣の乱れは幅広い ストレス反応と関連することが明らかとなった。長期 休業期間中における生活習慣の変化とストレス反応 · メンタルヘルスとの関連を検討した研究が少ないなか (Hu et al., 2020), このような知見は, COVID-19 流行 下に扔ける小学生のメンタルヘルスを理解し, 支援す るうえで, 重要な示唆を提供することができると考え られる。特に食習慣の変化がストレス反応と広く関連 していたことから，食習慣を維持することが，生活習 慣全般の安定と, ストレス反応の抑制につながる可能 性があると考えられる。

一方, 本研究では, 先行研究をもとに 7 領域を設定 し, 21 項目を独自に作成し, これらの平均得点を使 用した。しかし, これらの項目及び得点については, 妥当性が検討されているとはいえない。今後は, これ らの項目及び得点について妥当性を検証することが求 められる。

また, ストレス反応については, 臨時長期休業前の 状態については把握できていない。そのため, 生活習 慣の変化とストレス反応との因果関係を明らかにする ことはできない。この点については, 縦断調査など中. 長期的な視点で, 臨時休業期間中の生活習慣の変化と その後の小学生の生活習慣やストレス反応などの関連 について, 検討することが求められる。

また, 本研究では, 6 年生の親は調查対象者とはし なかった。6 年生は卒業式の簡素化または中止, 中学 校への環境意向など, $1-5$ 年生とは置かれている状 況が異なると考えたためであったが，それにより6年 生の生活習慣やストレス反応の特徵を把握することが できなかった。小学校から中学校への環境移行を目前 とした 6 年生にとって臨時長期休業がどのような影響 
があったかについては，今後検討すべき課題である。

さらに，本研究では親を対象に調査を実施した。こ れは, ベネッセ教育総合研究所 (2020) などと同様の 手法であり，また得られた結果は，先行研究と照らし ても解釈可能なものであった。しかし，親の認知と子 ども本人の認知は必ずしも一致するものではない。今 後は, 学校の臨時長期休業が子どもに及ぼした影響に ついて，子ども本人からのデータをもとに検討してい くことが求められる。

\section{利益相反}

本論文に関して，開示すべき利益相反関連事項はな い。

\section{引用文献}

Bates, L., Zieff, G., Stanford, K., Moore, J. B., Kerr, Z. Y., Hanson, E. D., ... Stoner, L. (2020). COVID-19 impact on behaviors across the 24-hour day in children and adolescents: Physical activity, sedentary behavior, and sleep. Children, 7, 138. https://doi.org/10.3390/ children7090138

Becker, S. P., \& Gregory, A. M. (2020). Perils and promise for child and adolescent sleep and associated psychopathology during the COVID-19 pandemic. Journal of Child Psychology and Psychiatry and Allied Disciplines, 61, 757-759.

ベネッセ教育総合研究所 (2020). 幼児・小学生の生 活に対する新型コロナウイルス感染症の影響調査 ベネッセ教育総合研究所 Retrieved from https:// berd.benesse.jp/up_images/research/COVID19 research_digest_1118.pdf（2020 年 12 月 8 日）

Biddle, S. J., \& Asare, M. (2011). Physical activity and mental health in children and adolescents: A review of reviews. British Journal of Sports Medicine, 45, 886895.

Gregory, A. M., \& Sadeh, A. (2012). Sleep, emotional and behavioral difficulties in children and adolescents. Sleep Medicine Reviews, 16, 129-136.

長谷川 爽・桝川 由布子・關 奏・赤松 利恵 (2018). 小学生における男女及び発達段階別の過体重に関 連する生活習慣の特定 日本健康教育学会誌, 26, 123-132.

服部 伸一・野々上 敬子・門田 新一郎 (2009). 小学 生の自覚症状の訴え数とライフスタイル要因の関 連について——数量化 II 類を用いた検討一一小 児保健研究, 6, 643-653.

Hu, Z., Lin, X., Kaminga, A. C., \& Xu, H. (2020). Impact of the COVID-19 epidemic on lifestyle behaviors and their association with subjective well-being among the general population in Mainland China: Cross-sectional study. Journal of Medical Internet Research, 22, e21176. https://doi.org/10.2196/21176

Janssen, I., \& LeBlanc, A. G. (2010). Systematic review of the health benefits of physical activity and fitness in school-aged children and youth. International Journal of Behavioral Nutrition and Physical Activity, 7, 40. https://doi.org/10.1186/1479-5868-7-40

Jiao, W. Y., Wang, L. N., Liu, J., Fang, S. F., Jiao, F. Y., Pettoello-Mantovani, M., \& Somekh, E. (2020). Behavioral and emotional disorders in children during the COVID-19 Epidemic. European Paediatric Association, 221, 264-266.

嘉数 朝子・井上 厚・田場 あゆみ（1999）。児童の生 活習慣と心理的ストレス一一性格特性と低体温と の関連で——琉球大学教育学部紀要, 55, 221232.

加藤 和代 · 大平 曜子 - 國土 将平 (2014). 小学生の 生活習慣と心の健康との因果構造 発育発達研 究, 63, 6-17.

国立成育医療研究センター (2020). コロナメこども アンケート第 1 回調査報告書 国立成育医療研 究センター Retrieved from https://www.ncchd.go. $\mathrm{jp} / \mathrm{center} /$ activity/covid19 kodomo/report/ report_01.pdf (2020 年 12 月 8 旦)

Kontoangelos, K., Economou, M., \& Papageorgiou, C. (2020). Mental health effects of COVID-19 pandemia: A review of clinical and psychological traits. Psychiatry investing, 17, 491-505.

小谷 正登（2019）。 子どもの睡眠習慣と心身の状態の 関連に関する研究一一学生対象の生活実態調査 の結果をもとに一教職教育研究 教職教育研 究センター紀要 (関西学院大学), 24, 19-29.

栗山 和広·田中 陽子·園田 順一・柴田 良一 (2001). 小中学生の無気力感と攻撃性に関する研究 日本 教育心理学会第 43 回総会発表論文集, 189 .

Lee, J. (2020). Mental health effects of school closures during COVID-19. Lancet Child and Adolescent Health, 4, 421. https://doi.org/10.1016/S2352-4642 (20)30109-7

Macht, M. (2008). How emotions affect eating: A five-way model. Appetite, 50, 1-11.

Medrano, M., Cadenas-Sanchez, C., Oses, M., Arenza, L., Amasene, M., \& Labayen, I. (2020). Changes in lifestyle behaviors during the COVID-19 confinement in Spanish children: A longitudinal analysis from the MUGI project. Pediatric Obesity, 16 (4), e12731. https://doi.org/10.1111/ijpo.12731

文部科学省 (2020a). 学校の臨時休業の実施状況, 取 り組み事例について (令和 2 年 3 月 19 日時点) Retrieved from https://www.mext.go.jp/a_menu/ coronavirus/index_00006.html（2020 年 4 月 17 日）

文部科学省 (2020b). 新型コロナウイルス感染症対策 に関する学校の新学期開始状況等について Retrieved from https://www.mext.go.jp/content/ 20200413-mxt_kouhou01-000006421_1.pdf（2020 年 4 月 17 日)

中岡 加奈絵 · 野田 聖子 · 山田麻子 - 並木 直子 · 五 関-曽根 正江 (2019). 小学校高学年児童におけ る学力と体力, 食習慣・生活習慣との関連 日本 女子大学大学院紀要 家政学研究科 - 人間生活学 研究科, 25, 1-10.

日本学校保健会（2018）。平成 28-29 年度 児童生徒 
の健康状態サーベイランス事業報告書 Retried from https://www.gakkohoken.jp/book/ebook/ebook H290070/index h5.html\#1（2020 年 10 月 6 日）

岡安 孝弘 - 由地 多恵子 - 高山 嚴 (1998). 児童用义 ンタルヘルス・チェックリスト（簡易版）の作成 とその実践的利用 宮崎大学教育学部教育実践研 究指導センター研究紀要, 5, 27-41.

Paruthi, S., Brooks, L. J., Ambrosio, C. D., Hall, W. A., Kotagal, S., Lloyd, R. M., ... Wise, M. S. (2015). Consensus statement of the American Academy of sleep medicine on the recommended amount of sleep for healthy children: Methodology and discussion. Journal of Clinical Sleep Medicine, 12, 1553-1561.

辻本 洋子·奥田 豊子·小山 達也·由田 克士 (2014). 大阪府内小学生の朝食摂取頻度と食行動 - 生活習 慣との関連 生活科学研究誌, 13, 55-63.

上地 広昭. 竹中 晃二・岡 浩一朗 (2000). 子どもの 身体活動とストレス反応の関係 健康心理学研 究, 13(2), 1-8.

上地 広昭・田中 祐二・長岡 聖子 (2008). 小学生に おけるストレス・マネジメント行動を獲得させる ための試験的試み——リラクセーション技法とア
クティベーション技法を比較して—— 健康心理 学研究, 21,31-38.

Vanderloo, L. M., Carsley, S., Aglipay, M., Cost, K. T., Maguire, J., \& Birken, C. S. (2020). Applying harm reduction principles to address screen time in young children amidst the COVID-19 pandemic. Journal of Developmental and Behavioral Pediatrics, 41, 335336.

山田 玲子・木下 紗希 · 岡田 忠雄 (2018). 小学生の 食習慣・食意識と心身の健康状態との関連 北海 道教育大学紀要 (教育科学編), 69, 353-358.

山西 奈津子 - 池田 順子 (2007). 小学生の食生活 · 生活習慣と心身の健康状態 京都文教短期大学研 究紀要, 46, 10-19.

Yeasmin, S., Banik, R., Hossain, S., Hossain, N., Mahumud, R., Salma, N., \& Hossain, M. (2020). Impact of COVID-19 pandemic on the mental health of children in Bangladesh: A cross-sectional study. Children and Youth Services Review, 117, 105277. https://doi. org/10.1016/j.childyouth.2020.105277

- 2020.9.4 受稿, 2021.5.1 受理——

\section{付 録}

「生活習慣の変化」として回答を求めた項目

(a) 不規則な睡眠

就寝時間が不規則になった

普段よりも起きる時間が遅くなった

規則正しい睡眠リズムを維持していた※

（b）食習慣の乱れ

食事の量が変わった（增えた/減った）

食事をとる時間がバラバラになった

間食や不規則な食事が多かった

(c) 学習時間の減少

いつもよりも勉強する量が少なかった

勉強に取り組む時間が少なかった

しっかり計画立てて学習を行っていた※

（d）外出の減少

外出する機会が減った

家の中で過ごすことが多くなった

買い物や遊び，散歩などで外に出るようにしていた※

（e）テレビ・ネット視聴の増加

テレビやインターネットを見ている時間が増えた

いつもテレビやインターネットをみていた

テレビやインターネットをだらだらと見続けていた

(f) 運動の滅少

これまでよりも運動しなくなった

いつも以上にスポーツに取り組んでいた※

運動する時間がいつもより少なかった

（g）ゲーム・スマホ利用の増加

ゲームやスマートフォンをいつもよりも長く利用していた

ゲームやスマートフォンで長時間遊んでいた

いつもよりゲームやスマートフォンに触れる時間が少なかった※

注）※は逆転項目を意味する。 